\title{
160Gbit/s ATM交換システムにおけるマルチチップモジュール技術
}

\author{
岸本 亨*, 海津 勝美**, 佐々木 伸一*** \\ Multi Chip Module Technologies for High-Throughput ATM Switching Systems
}

Tohru KISHIMOTO* Katsumi KAIZU** and Shinichi SASAKI***

*NTT研究開発推進部総括部門 (₹163-19 東京都新宿区西新宿3-19-2)

**NTTネットワークサービスシステム研究所伝達システム研究部（†180 東京都武蔵野市緑町3-9-11）

***NTT光エレクトロニクス研究所光応用装置研究部（广180 東京都武蔵野市緑町3-9-11）

*R\&D Management Department, NTT (3-19-2 Nishishinjuku, Shinjuku-ku, Tokyo 163-19)

**Network Service System Labs., NTT (3-9-11 Midori-cho, Musashino-shi, Tokyo 180)

*** Optical Hardware Systems Labs., NTT Opto-electronics Laboratories (3-9-11 Midori-cho, Musashino-shi, Tokyo 180)

\section{| 1. はじめに}

音声，データ，映像などの各種マルチメディアを効率的 に伝送でき，今後の広帯域通信網の核となるATM (Asynchronous Transfer Mode，非同期転送モード) シス テムの研究開発が各国で盛んに行われている。公衆網用装 置のみならず，広帯域LANの 1 つとしてATM LAN装置の 開発・実用化がアメリカを中心に活発化している。

VOD(Video On Demand)等のマルチメディア通信を実現 する広帯域通信サービスは，21世紀には現在の電話サービ ス程度まで普及するものと予想されており，サブテラビッ 卜級のスループットを有するATM交換システムが必要に なる。例えばATM交換システムの規模を拡張するため， 加入者線を収容する $10 \mathrm{Gbit} / \mathrm{s}$ 程度のスループットを有する 交換ノード(AHM：ATM Circuit Handling Module)を, 相 互に接続することを目的とするノード間接続装置(AMC：

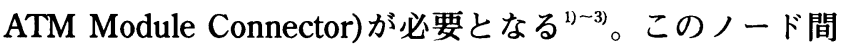
接続装置もATM交換システムであり, 統計多重効果のメ リットを十分に生かせる等の理由から，10Gbit/s級の高速 回線を収容する小型なスイッチが望ましい。そこで高速デ バイスと高速実装技術を適用し，スループット160Gbit/s を有する入出力バッファ型高速ATM交換システムを実現 した(4)-8)。

本稿では，上記ATM交換システムの中核であるクロス ポイントスイッチ部を実現する上でのキーとなる, 高速実 装技術，特にマルチチップモジュール $(\mathrm{MCM})$ 技術および その周辺技術を中心に概観する。

\section{| 2. ATM交換システムの構成概要}

図 1 に，入出力バッファ型高速ATM交換システムのブ ロック構成を示す。入出力回線ごとにセルバッファを配置 し, 入出力バッファ間はクロスポイントスイッチで接続さ
れる。ブロッキングの影響を低減し，スイッチスループッ 卜を向上させるため，七ルはクロスポイントスイッチ内を 入出力速度の 2 倍( $20 \mathrm{Gbit} / \mathrm{s}) て ゙$ 転送される ${ }^{4) .5)}$

したがって，回線ごとにセルバッファを設けることで回 線速度をセルバッファの最高速度まであげることができ， クロスポイント間を最短で高速に接続でき，さらに同位置 出力宛先を有するセルの衝突制御を各クロスポイントで実 現できるといった特徴を有している。なお本システムでは， クロスポイントスイッチ部にMCM技術を適用し, 高速・ 高密度実装を実現している。

\section{| 3. ATM交換システムの実装構成}

\section{1 構成概要}

図 2 にMCMを適用したクロスポイントスイッチ部の断 面構造を示す。また表 1 に適用したクロスポイントスイッ チの諸元を示す9”。280端子を有するスイッチLSI 4 つを KGDの観点からTAB技術を用いて, 銅一ポリイミド多層 配線板にフェースアップで搭載している。各MCM間には 多数の接続を必要とするため, 表面搭載型の高密度・高速 なFPCケーブルコネクタを開発した。本コネクタを適用す ることにより，高速信号経路をMCM表面上に構成し，コ ネクタ領域の削減によりMCMの小型化を実現した。電源 およびクロックは，MCM裏面側に設けた疑似同軸型 MCM コネクタ（クロックのみ疑似同軸構成）より供給し た。また MCM当たり $30 \mathrm{~W} と$ 高発熱であるが，放熱は MCM裏面に設けたコールドプレートを介してヒートパイ プによってサブモジュール搭載基板裏面に導き，凝縮部を 強制空冷することにより実現している。

このような構成とすることにより，MCM間の高速信号 を最短距離で接続でき, 表 2 に示すような小型で高速なシ ステムを実現可能にした。以下にMCM実装を支える各要 素技術を詳述する。 


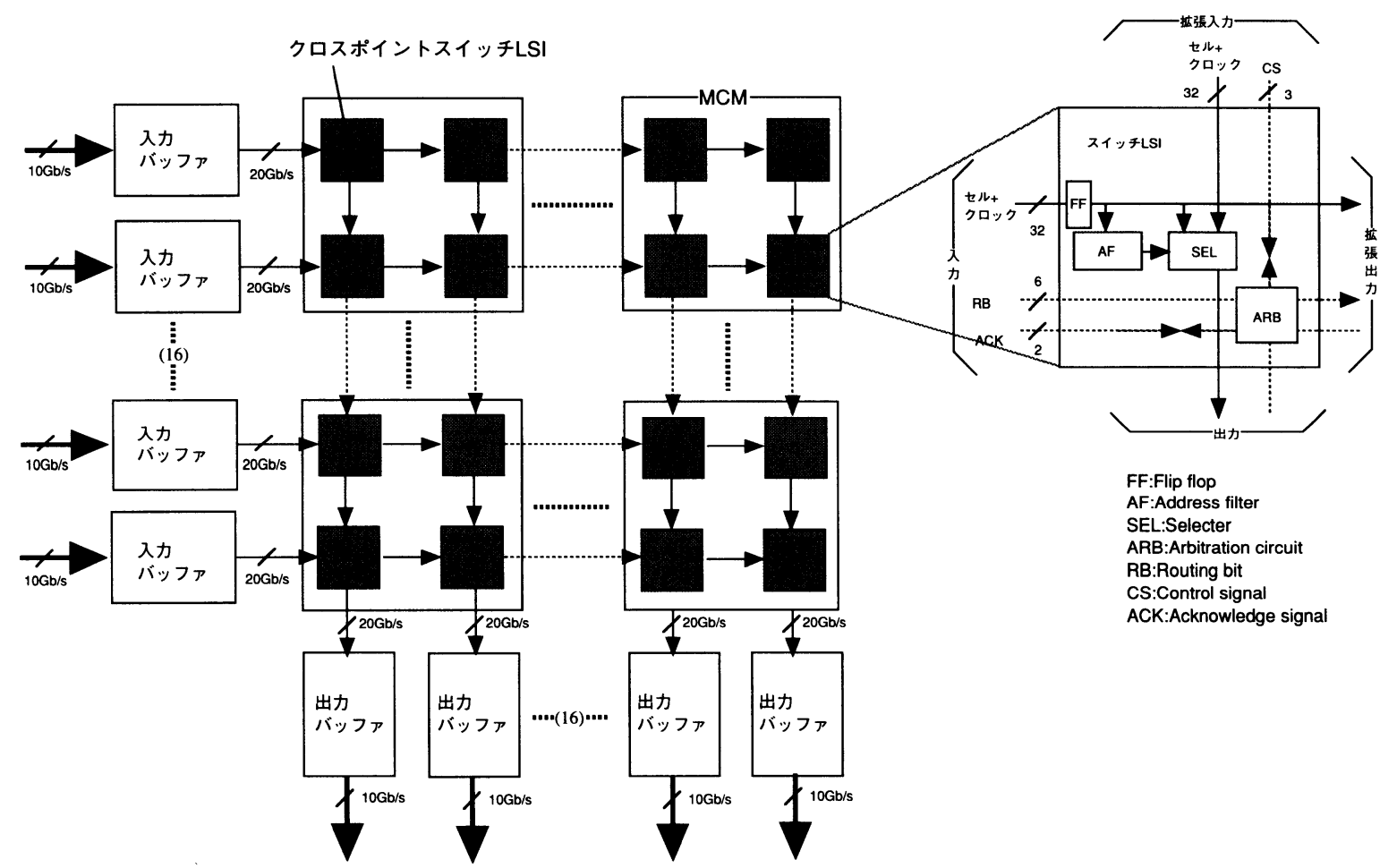

図1. ATMスイッチのブロック瞥成

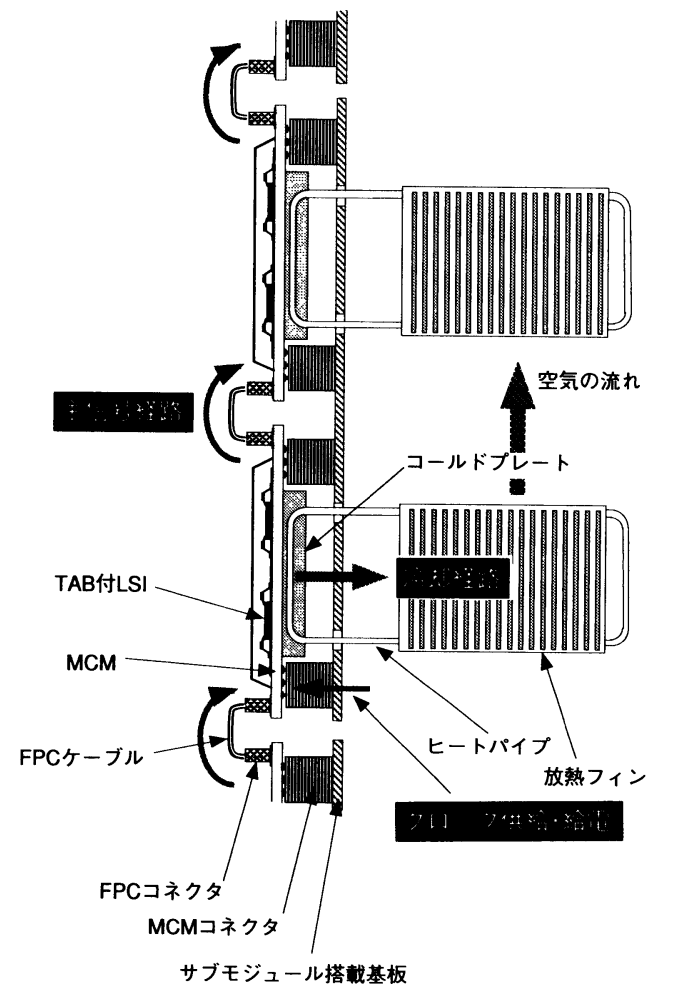

図2. ATMスイッチMCMの梅造(側面図)

\section{2 TAB技術}

MCMへの搭載前にスイッチLSIの良品選別を行うため, TABを用いて基板搭載を行った。また基板搭載エリアと TABリードのインダクタンス低減のため, アウタリードピ ッチ $150 \mu \mathrm{m}$ を実現した。更に検査後の不良チップリペアの ため，基板への搭載にははんだを適用した。搭載状況を図 3 に示す。
表1. スイッチLSIの諸元

\begin{tabular}{l|l}
\hline アーキテクチャ & $1 \times 1$ クロスポイントスイッチ \\
スイッチスループット & $20 \mathrm{Gbit} / \mathrm{s}(622 \mathrm{Mbit} / \mathrm{s} \times 32)$ \\
動作速度 & $900 \mathrm{Mbit} / \mathrm{s}$ \\
I/Oレベル & $\mathrm{ECL} 100 \mathrm{~K}$ \\
回路技術 & $1.0 \mu \mathrm{m} \mathrm{Super} \mathrm{Selfalign} \mathrm{Technology}$ \\
消費電力 & $7.0 \mathrm{~W}$ \\
電源電压 & $-4.5 \mathrm{~V},-2.0 \mathrm{~V}$ \\
内部ゲート数 & 4000 \\
チップサイズ & $7.5 \mathrm{~mm} \times 9.56 \mathrm{~mm}$ \\
入出力端子数 & 280 \\
\hline
\end{tabular}

表2. システムの実装諸元

\begin{tabular}{|c|c|c|}
\hline LSIチップ & $\begin{array}{l}\text { サイズ } \\
\text { 端子数 } \\
\text { 消費電力 } \\
\text { ILBピッチ } \\
\text { OLBピッチ } \\
\end{array}$ & $\begin{array}{l}7.5 \times 9.56 \mathrm{~mm} \\
280 \text { (信号:195, 電源:85) } \\
6.0 \text { watts } \\
110 \mu \mathrm{m} \\
150 \mu \mathrm{m}\end{array}$ \\
\hline $\mathrm{MCM}$ & $\begin{array}{l}\text { サイズ } \\
\text { 端子数 } \\
\text { 層構成 } \\
\text { 消費電力 } \\
\text { 搭載チップ数 }\end{array}$ & $\begin{array}{l}60 \times 60 \mathrm{~mm} \\
784 \mathrm{FPC} \text { コネクタ経由, 152給電ピン } \\
4 \text { 層(Cu/PI)+15層(セラミック基板) } \\
30 \text { watts } \\
\text { (終端抵抗による電力消費を含む) } \\
2 \times 2\end{array}$ \\
\hline $\begin{array}{l}\text { サブモジュール } \\
\text { 搭載ボード }\end{array}$ & $\begin{array}{l}\text { サイズ } \\
\text { 層菁成 } \\
\text { 搭載MCM数 }\end{array}$ & $\begin{array}{l}139 \times 139 \mathrm{~mm} \\
3 コ ア+3 \text { 層 } \\
2 \times 2\end{array}$ \\
\hline ヒートパイプ & $\begin{array}{l}\text { 高さ } \\
\text { コールドプレートサイズ } \\
\text { ヒートシンクサイズ } \\
\text { 動作液 }\end{array}$ & $\begin{array}{l}175 \mathrm{~mm} \\
40 \times 40 \times 2 \mathrm{~mm} \\
30(\mathrm{~W}) \times 30(\mathrm{~L}) \times 30(\mathrm{H}) \mathrm{mm} \\
\text { フレオン } 42 \mathrm{~b}(\mathrm{CH} 3 \mathrm{CCIF} 2)\end{array}$ \\
\hline
\end{tabular}




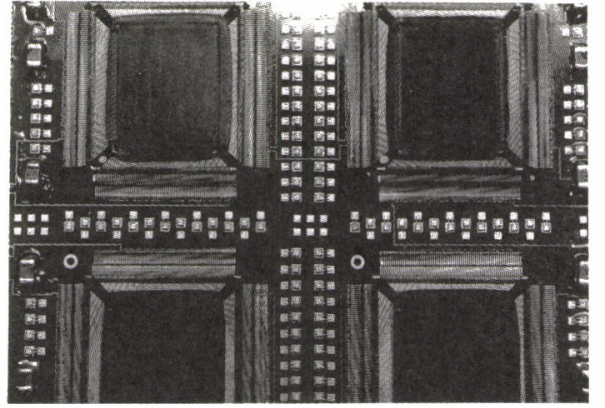

図3. TAB搭載部

\section{3 MCM基板}

図 4 にスイッチLSIを 4 個搭載したMCMの外観を (MCM当たりのスループットは $40 \mathrm{Gbit} / \mathrm{s})$ ，また図 5 に層 構成を示す。MCM表面側周辺には高速信号用の，また裏 面周辺にはクロックおよび給電用のI/O端子を有してい る。銅一ポリイミド配線内層の高速信号配線は特性インピ ーダンスと配線長ばらつきを高精度に制御するとともに， OLBパッド直下に $50 \Omega$ の薄膜終端抵抗を 320 個形成してい る。LSIの直下は低熱抵抗化を図るため，熱放散用に銅柱 ビアを形成している ${ }^{10) ~ 12)}$

セラミック層内には電源系のインピーダンスを低減する ため, $50 \mu \mathrm{m}$ 厚のシートを積層し，ラミネートコンデンサ を形成している。

図 6 は銅一ポリイミド配線層に形成した高速信号線のパ

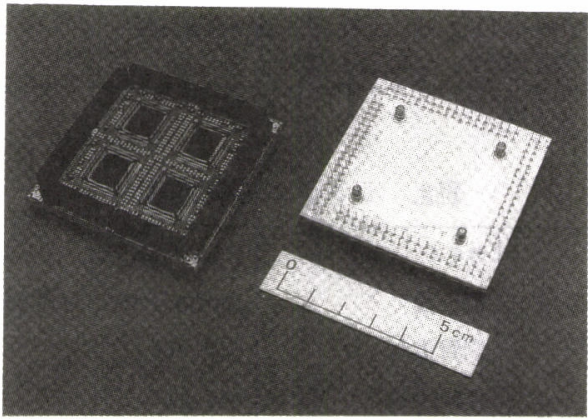

図4. マルチチップモジュールの外観

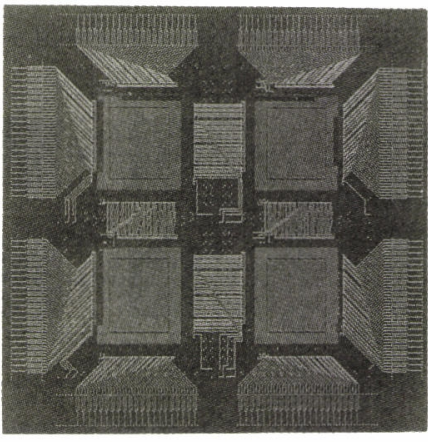

図6. 高速信号用配線パターン

ターンを示したものであり, 配線幅 $25 \mu \mathrm{m}$, ピッチ $150 \mu \mathrm{m}$ である。すべてストリップライン構成であり, 特性インピ

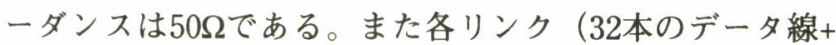
併走クロック+制御信号で構成される）配線の長さを高精 度に制御し，長さのばらつきを $150 \mu \mathrm{m}$ 以下に抑えている。 なお特性インピーダンス, および薄膜終端抵抗のばらつき について実測した結果を表 3 に示す。

\section{4 サブモジュール搭載基板}

本基板にはMCMが 4 個搭載され（スループットは $80 \mathrm{Gbitb} / \mathrm{s})$, クロックの供給と, 給電を行う。クロックは ストリップライン構造を持つ専用層で配線しており, 給電 は比誘電率10のテフロン樹脂を $0.5 \mathrm{~mm}$ 厚の銅コアで挟んだ 構成であり，電源層の低インピーダンス化と，最大 $32 \mathrm{~A} の$ 大電流を給電可能とした。

\subsection{FPCコネクタおよびケーブル}

スイッチMCM間の高速信号を伝送するため，高密度・ 多端子FPCコネクタおよびケーブルを開発した ${ }^{13)-17)}$ 。図 7 にその外観を示す。FPCケーブルは長さ $40 \mathrm{~mm} ， 98$ 本のマ

表3., 基板の電気特性

\begin{tabular}{|c|c|c|c|c|c|c|c|}
\hline \multirow{3}{*}{$\mathrm{Z}_{0}$} & \multirow[b]{2}{*}{ 基板内 } & \multicolumn{2}{|c|}{$\begin{array}{c}\text { セラミック基板 } \\
(100 \mu \mathrm{m} \text { 幅 })\end{array}$} & \multicolumn{2}{|c|}{$\begin{array}{l}\mathrm{Cu} / \mathrm{PI} \text { 基板 } \\
(25 \mu \text { m幅 })\end{array}$} & \multicolumn{2}{|c|}{$\begin{array}{l}\text { 薄膜抵抗 } \\
(25 \mu \mathrm{m} \square)\end{array}$} \\
\hline & & $48.48 \Omega$ & $\begin{array}{l}+2.3 \% \\
-1.6 \%\end{array}$ & $47.40 \Omega$ & $\begin{array}{l}+2.1 \% \\
-1.6 \%\end{array}$ & $51.50 \Omega$ & $\begin{array}{l}+4.3 \% \\
-4.3 \%\end{array}$ \\
\hline & 基板間 & $49.14 \Omega$ & $\begin{array}{l}+0.7 \% \\
-1.1 \% \\
\end{array}$ & $47.80 \Omega$ & $\begin{array}{l}+6.5 \% \\
-6.4 \% \\
\end{array}$ & $51.50 \Omega$ & $\begin{array}{l}+15.0 \% \\
-14.0 \% \\
\end{array}$ \\
\hline \multicolumn{2}{|c|}{ 遅延時間 } & \multicolumn{2}{|c|}{$114 \mathrm{ps} / \mathrm{cm}$} & \multicolumn{2}{|c|}{$60 \mathrm{ps} / \mathrm{cm}$} & \multicolumn{2}{|c|}{-} \\
\hline
\end{tabular}

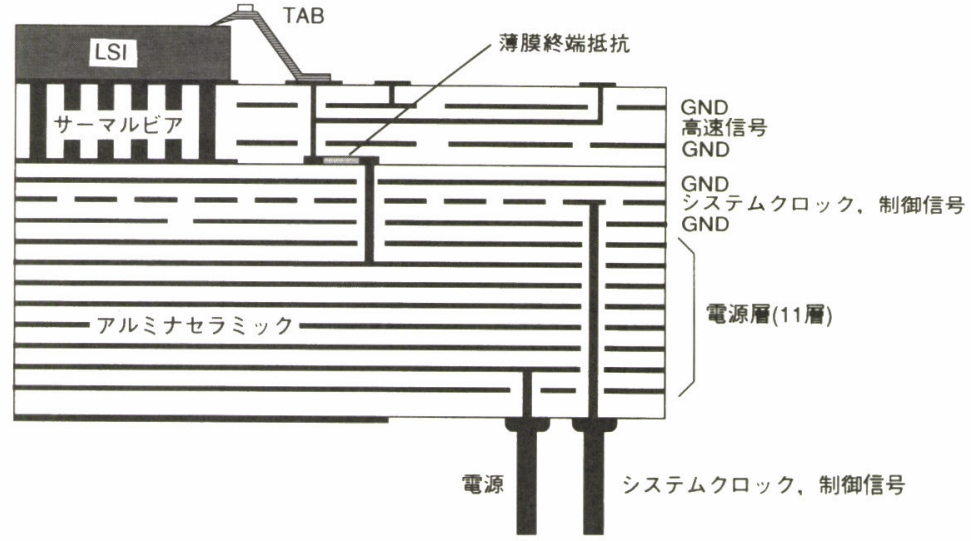

図5. MCM層構成 


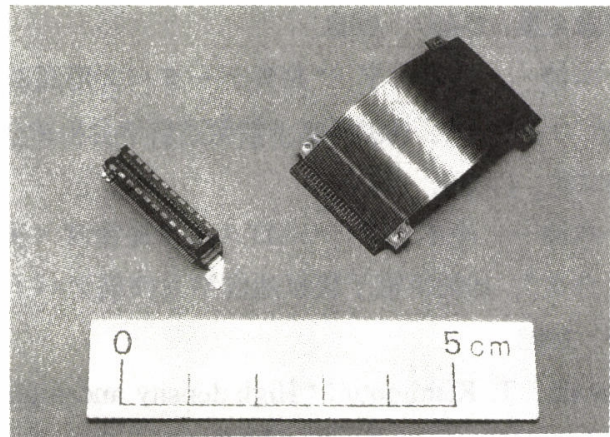

図7. FPCコネクタ,ケーブルの外観

イクロストリップライン構造の配線を有する。FPCケーブ

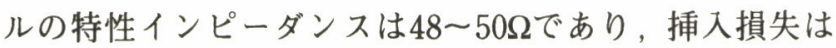
$600 \mathrm{MHz}$ で0.5dBである。

またFPCコネクタは, 端子ピッチ0.4mmの表面実装型コ ネクタであり, 高速信号を伝送するため, 信号とグランド 端子が 1 ：1の割合で交互に配置してあり，搭載エリアは 幅 $6 \mathrm{~mm}$, 長さ $23 \mathrm{~mm}$ と小型である。このため $\mathrm{MCM}$ サイズ の大幅な小型化を可能にした。

\section{6 疑似同軸MCMコネクタ}

MCMへのクロック供給と給電のため, 疑似同軸型

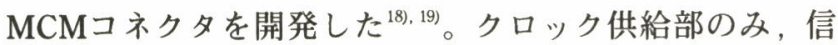
号コンタクトの周りを, グランドコンタクトと一体プレス 成形したグランドプレートで覆い，信号コンタクト部を疑 似同軸化した構造である。本コネクタは38心のコンタクト からなり，このうち 8 コンタタト（4信号）が疑似同軸構 造となっている。疑似同軸部の特性インピーダンスは $50 \Omega \pm 3 \Omega$ あり，挿入損失も $2 \mathrm{GHz}$ で $0.6 \mathrm{~dB}$ と小さ。

\section{7 ヒートパイプ}

図 2 に示すように, MCMの表裏面ともにコネクタで囲 われた構成であることから，MCMに直接ヒートシンクを 搭載し，空冷することは困難である。このため，MCM裏 面にコールドプレートを接続し，熱をサブモジュール基板 裏面の空間に導くため, 図 8 に示すヒートパイプならびに ヒートパイプで構成するヒートシンクを開発した ${ }^{20) .21}$ 。 MCM当たりの消費電力は $30 \mathrm{~W}$ 高発熱であるにもかかわ らず，風速 $2 \mathrm{~m} / \mathrm{s}$ の強制空冷でLSI当たりの熱抵抗 $0.7^{\circ} \mathrm{C}$ /Wを実現している。

\section{8 サブモジュールおよびシステムの外観}

これまで示した各要素部品を, 図 9 に示すアセンブルフ ローに従い組み立てを行い, 図10に示すサブモジュールお

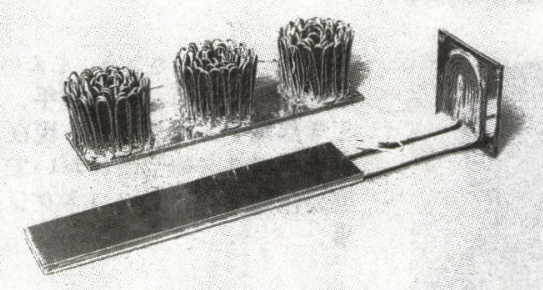

図8. ヒートパイプの外観

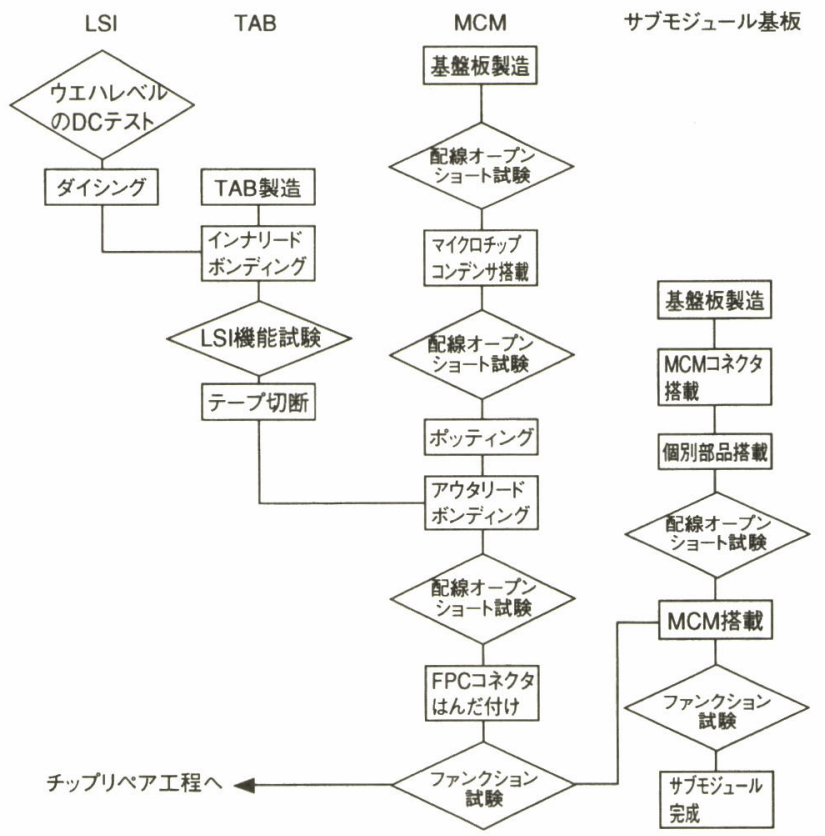

図9. アセンブル工程

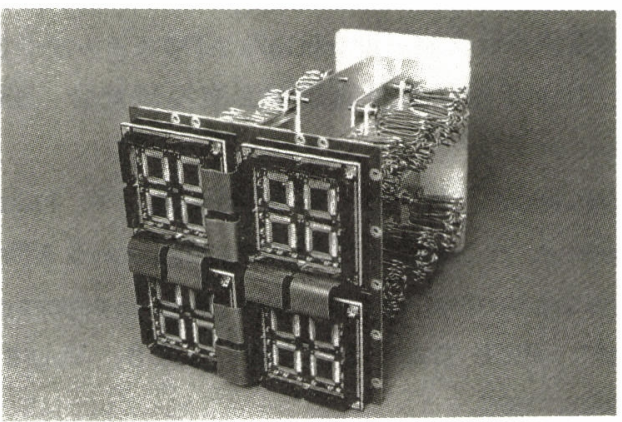

図10. サブモジュールの外観

よび図11に示すサブモジュール16個をマトリックス状に配 置したスループット $160 \mathrm{~Gb} / \mathrm{s}$ 有するATM交換システムを 実現した。各信号ラインで $600 \mathrm{Mbit} / \mathrm{s}$ 以上, リンク当たり で20Gb/sの高速セル転送が実現できることを確認してお り ${ }^{4) ~}$ ，ここで示した実装技術を適用することにより，サ ブテラビット級のATM 交換システムを実現できる。

\section{| 4. まとめ}

160Gbit/sのスイッチスループットを有するATM交換シ ステムを実現する上で必須な高密度実装技術である MCM 技術抢よびその周辺技術について示した。

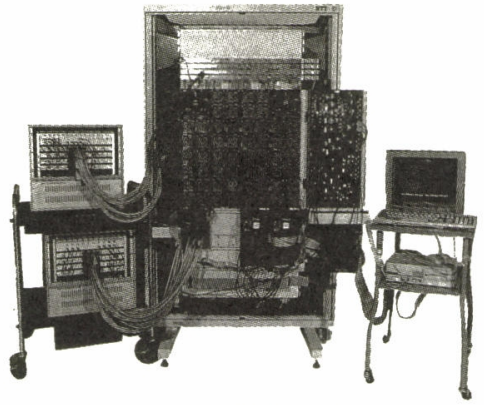

図11. システムの外観 
本技術を用いることにより，広帯域通信サービス普及 時のサブテラビット級スループットを有する高速・大容 量ATM交換システムを実現できる見通しが得られた。

(1996.5.21-受理 1996.6.24-再受理)

\section{文献}

1）宮保憲治, 土井幸浩, 平野美貴, 高木康志：“ATM交換シ ステム構成技術”, NTT R\&D, Vol.42, No.3, pp.283-295， 1993.

2) H. Miyaho, M. Hirano, Y. Takagi: "ATM switching system architecture for first generation of broadband services”, ISS '92, Oct., 1992.

3）濃沼健夫，高橋達郎：“ATMノードシステム技術”, NTT R\&D, Vol.42, No.3, pp.275-282, 1993.

4）源田浩一, 遠藤乾一, 川村智明, 岸本 亨：“MCM技術を 用いた $160 G$ Gb/s ATMスイッチの試作”，1994年電子情報通 信学会春季全国大会講演論文集, 1994.

5) 源田浩一, 遠藤乾一, 福田秀樹, 川村智明, 岸本 亨 : “内部高速クロスバー型 $160 \mathrm{~Gb} / \mathrm{s} \mathrm{ATMスイッチングシステ}$ ム”, 1994年電子情報通信学会交換研究会, SSE94-79, 1994.

6) Y. Yamanaka, K. Endo, K. Genda, H. Fukuda, T. Kishimoto, S. Sasaki : “ $320 \mathrm{~Gb} / \mathrm{s}$ high-speed ATM switching system hardware technologies based on copper-polyimide MCM", IEEE Trans. on CPMT part B, Vol.18, No.1, pp.83-91, 1995.

7) K. Genda, N. Yamanaka, Y. Doi, T. Kishimoto, S. Sasaki, H. Fukuda : " $80 \mathrm{~Gb} / \mathrm{s}$ ATM switching module based on copper-polyimide MCM", IEE Electronics Letters, Vol.31, No.9, pp.716-717, 1995.

8) 岸本 亨, 海津勝美, “ATMシステムにおける高密度実装 技術”，回路実装学会誌，Vol.11，No.2, pp.133-139，1996.

9) T. Kawamura, H. Ichino, M. Suzuki, K. Genda, Y. Doi : "An over $20 \mathrm{~Gb} / \mathrm{s}$ throughput Si-bipolar ATM crosspoint switch LSI", IEE Electronics Letters, Vol.30, No.11, pp.854-855, 1994.

10) 源田浩一, 山中直明, 岸本 亨, 佐々木伸一: “高密度実 装における電源ノイズからの信号転送速度制限の検討”, 1992年電子情報通信学会秋季全国大会講演論文集, B-390, 1992.

11) 佐々木伸一, 岸本 亨, 海津勝美, 源田浩一：“高速 ATM スイッチ用マルチチップモジュール”，1994年電子情報通 信学会秋季全国大会講演論文集, 1994.

12) S. Sasaki, T. Kishimoto, K. Kaizu, K. Genda, K. Endo : "Multichip module technologies for high-speed ATM switching systems", 3rd IC\&E MCM, pp.130-135, 1994.

13）佐々木伸一, 岸本 亨: “高速データバス用多端子FPCコネ クタの伝送特性”，1993年電子情報通信学会春季全国大会
講演論文集，C-427, 1993.

14）佐々木伸一, 岸本 亨: “高速データバス用高密度・多端 子FPCコネクタ”, 1993年電子情報通信学会秋季全国大会講 演論文集, C-326, 1993.

15) 佐々木伸一, 岸本 亨: “SMTタイプ高密度・多端子FPC コネクタ”, 1993年電子情報通信学会機構デバイス研究会 資料, 1993.

16) S. Sasaki, T. Kishimoto : "High-density and high-pin-count flexible SMD connector for high-speed data bus”, 1993 IEEE/CHMT IEMT Symposium, pp.411-416, 1993.

17）安田圭一, 中埜賢一, 岸本 亨：“通信用コネクタの技術 と動向”, 1994年電子情報通信学会機構デバイス研究会, 1994.

18）佐々木伸一, 岸本 亨, 杉浦伸明, 岡 宏規: “MCM用表 面搭載型同軸モジュールコネクタ”，1992年電子情報通信 学会機構デバイス研究会, 1992.

19）岸本亭，佐々木伸一：“疑似同軸型MCM 特性”, 1994年電子情報通信学会秋季全国大会講演論文集, C-435, 1994.

20) 岩田敏明, 岸本 烹, 佐々木伸一: “マルチチップモジュ 一ルのヒートパイプ冷却”, 1993年電子情報通信学会秋季 全国大会講演論文集, C-347, 1993.

21) T. Kishimoto, S. Sasaki, K. Kaizu, K. Genda, K. Endo : "Heat-pipe cooling technology for high-speed ATM switching multichip modules", IEICE Trans. on Electronics, Vol.E78-C, No.5, pp.567-573, 1995.

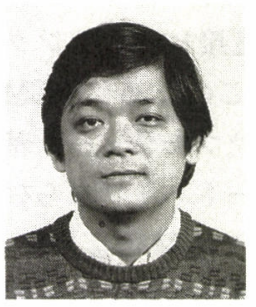

岸本 亨 (きしもととおる) 昭和 30 年生まれ。昭和 54 年, 慶應義塾大学 大学院工学部機械工学科修士課程修了。現 在NTT研究開発推進部において, 高速交 換システムの高速高密度実装技術開発に従 事。

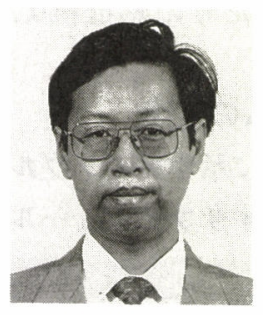

海津 勝美 (かいつ かつみ)

昭和24年生まれ。昭和48年, 東京電機大学 工学部電気工学科卒業。現在, NTTネット ワークサービスシステム研究所において, LSIの信頼性, 高速高密度実装技術の開発 に従事。

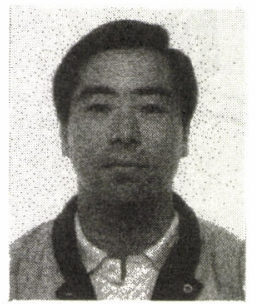

佐々木 伸一 (ささきしんいち) 昭和 35 年生まれ。昭和 57 年, 九州工業大学 工学部電子工学科卒業。現在, NTT光エレ クトロニクス研究所において, 高速高密度 実装技術, 光インタコネクション開発に従 事。 